We thank Miss B Watson, Miss V Drummond, and Miss V Algar for technical work, Mrs G Watkins for help with the statistics, and Mrs A Spink for secretarial help. C J is supported by the Medical Research Council. We are grateful to Novo Laboratories for a contribution towards expenses.

\section{References}

${ }^{1}$ Barnett AH, Eff C, Leslie RDG, Pyke DA. Diabetes in identical twins. Diabetologia $1981 ; 20: 87-93$.

2 Gottlieb MS, Root HF. Diabetes mellitus in twins. Diabetes 1968;17: 693-704.

${ }^{3}$ Nerup J, Platz P, Anderson OO, et al. HLA antigens and diabetes mellitus. Lancet 1974 ;ii:864-6.

4 Cudworth AG, Woodrow JC. Evidence for HLA-linked genes in "juvenile" diabetes mellitus. $\mathrm{Br}$ Med 7 1975;iii:133-5.

5 Sveigaard A, Platz P, Ryder LP, Staub-Nielsen L, Thomsen M. HL-A and disease association: a survey. Transplant Review 1975;22:3-43.

${ }^{6}$ Nelson PG, Pyke DA, Cudworth AG, Woodrow JC, Batchelor JR. Histocompatibility antigens in diabetic identical twins. Lancet $1975 ;$ ii $: 193-7$.

7 Cudworth AG. Type I diabetes mellitus. Diabetologia 1978;14:281-91.

${ }^{8}$ Svejgaard A, Platz P, Ryder LP. Joint report-insulin dependent diabetes.
In: Terasaki PI, ed. Histocompatibility testing. California: UCLA Tissue Typing Laboratory, 1980:638-56.

${ }^{9}$ Deschamps I, Lestradet EH, Bonäiti C, et al. HLA genotype studies in juvenile onset insulin dependent diabetes. Diabetologia 1980;19:189-93.

10 Platz $\mathrm{P}$, Jakobsen BK, Morling N, et al. HLA D and DR antigens in genetic analysis of insulin dependent diabetes mellitus. Diabetologia $1981 ; 21: 108-15$.

11 Svejgaard A, Ryder LP. HLA genotype distribution and genetic models of insulin dependent diabetes mellitus. Ann Hum Genet 1981;45:293-8.

12 Wolf E, Spencer KM, Cudworth AG. The genetic susceptibility to type 1 (insulin-dependent) diabetes. Analysis of the HLA DR association. Diabetologia (in press).

13 Tattersall RB, Pyke DA. Diabetes in identical twins. Lancet 1972;ii: 1120-5.

14 Van Rood JJ, Van Leeuwen A, Ploem JS. Simultaneous detection of two cell populations by two-colour fluorescence and application to the recognition of B cell determinants. Nature 1976;262:795-7.

${ }^{15}$ Christy M, Green A, Christau B, et al. Studies of the HLA system and insulin dependent diabetes mellitus. Diabetes Care 1979;2:209-14.

${ }^{16}$ Rotter JI, Congleton JE, Terasaki PI. An HLA genotype study of IDDm: excess and heterogeneity of DR3/DR4, heterozygotes [Abstract]. Diabetes 1982 ; suppl $2,64 \mathrm{~A}: 256$.

(Accepted 26 October 1982)

\title{
Long-term continuous intraperitoneal insulin treatment in brittle diabetes
}

\author{
G POZZA， D SPOTTI， P MICOSSI， M CRISTALLO, M MELANDRI, P M PIATTI, L D MONTI, \\ A E PONTIROLI
}

\begin{abstract}
Attempts to achieve a fair metabolic equilibrium in a young woman with brittle diabetes by continuous subcutaneous, intramuscular, and continuous intravenous administration of insulin were unsuccessful. Continuous intraperitoneal administration of insulin through a permanently inserted polyethylene catheter connected to an open-loop peristaltic pump led to an appreciable improvement in mean blood glucose concentration, mean amplitude of glycaemic excursions, and $M$ value and to normalisation of intermediate metabolic products. The peritoneal catheter was well tolerated for over 120 days without appreciable adverse effects.

This case suggests that long-term intraperitoneal administration of insulin is a feasible therapeutic approach in the management of brittle diabetes.
\end{abstract}

\section{Introduction}

Brittle diabetes is a heterogeneous clinical condition characterised by unpredictable swings in blood glucose concentration, an

Department of Medicine, Ospedale S Raffaele, 20132 Milan, Italy G POZZA, MD, professor of medicine and chairman D SPOTTI, MD, full-time staff physician

P MICOSSI, MD, research associate and staff physician

$M$ MELANDRI, $M D$, intern

P M PIATTI, MD, intern

L D MONTI, MD, intern

A E PONTIROLI, MD, vice-chairman

Department of Surgery, Ospedale $S$ Raffaele M CRISTALLO, MD, vice-chairman increased number of admissions to hospital, and changes in daily insulin requirement sometimes associated with altered or irregular insulin absorption. ${ }^{1}$ We report here attempts to control severe brittle diabetes in a young woman: continuous subcutaneous, intramuscular, or continuous intravenous administration of insulin was unsuccessful, but use of a permanent intraperitoneal catheter connected to a peristaltic pump resulted in fair metabolic equilibrium.

\section{Case report}

The patient, a 28 year old schoolmistress who was slightly overweight, had been diagnosed as diabetic in 1967, when she was 14, since when she had been receiving insulin treatment. After a year of relative equilibrium her diabetes had become unstable, with frequent episodes of ketosis; she had been admitted to hospital on at least 13 occasions over the past seven years because of hyperglycaemic coma and on numerous other occasions each year because of severe hypoglycaemia. Glycosylated haemoglobin concentration during the past year had been over $15 \%$; C peptide was undetectable in serum even during severe hyperglycaemia. She was first admitted to the metabolic ward of this hospital in October 1980; she was then twice admitted to the emergency departments of two other hospitals during the following months with a diagnosis of diabetic ketoacidosis, and she was readmitted to our metabolic ward in December 1981.

During the following 130 days different routes of insulin administration were tried-namely, continuous subcutaneous, intramuscular, continuous intravenous, and, finally, since these were all unsatisfactory, continuous intraperitoneal (using a peristaltic pump, Promedos E1; Siemens, West Germany). An intraperitoneal, silicone-coated, high-density polyethylene catheter (internal diameter $0.3 \mathrm{~mm}$, external diameter $0.7 \mathrm{~mm}$; Siemens) was inserted percutaneously through a 14-gauge Teflon cannula (Abbocath 14) $4 \mathrm{~cm}$ below the umbilicus on the linea alba, a needle introducer being used to make a 15-cm subcutaneous tunnel: this technique reduces the amount of subcutaneous tissue dissected, establishes accurately the point of exit from subcutaneous tissue, and increases the stability of the catheter. 
An acid insulin that does not crystallise or precipitate even when kept in the reservoir of an infusion device for one month was kindly provided by Hoechst Italia.

\section{Methods and results}

Blood glucose concentration was measured using reactive strips (Dextrostix), which were read with a reflectance meter (Dextrometer; Miles Ames, Indiana). Least squares regression analysis of the relation between blood glucose concentrations as determined by chemistrips and as measured in the laboratory using an autoanalyser yielded $r=0.968$. The mean amplitude of glycaemic excursions and the $M$ value, two variables of metabolic equilibrium, were calculated as described respectively by Service $e t a l^{2}$ and Schlichtkrull $e t a l^{3}$ for more than 150 blood glucose determinations for each different period of treatment. Blood glucose concentrations greater than $22 \mathrm{mmol} / \mathrm{l}$ $(396 \mathrm{mg} / 100 \mathrm{ml})$ were taken as being $25 \mathrm{mmol} / 1(451 \mathrm{mg} / 100 \mathrm{ml})$ in calculations of the mean amplitude of glycaemic excursions and the $M$ value.

The figure shows the seven-day glycaemic profiles obtained with

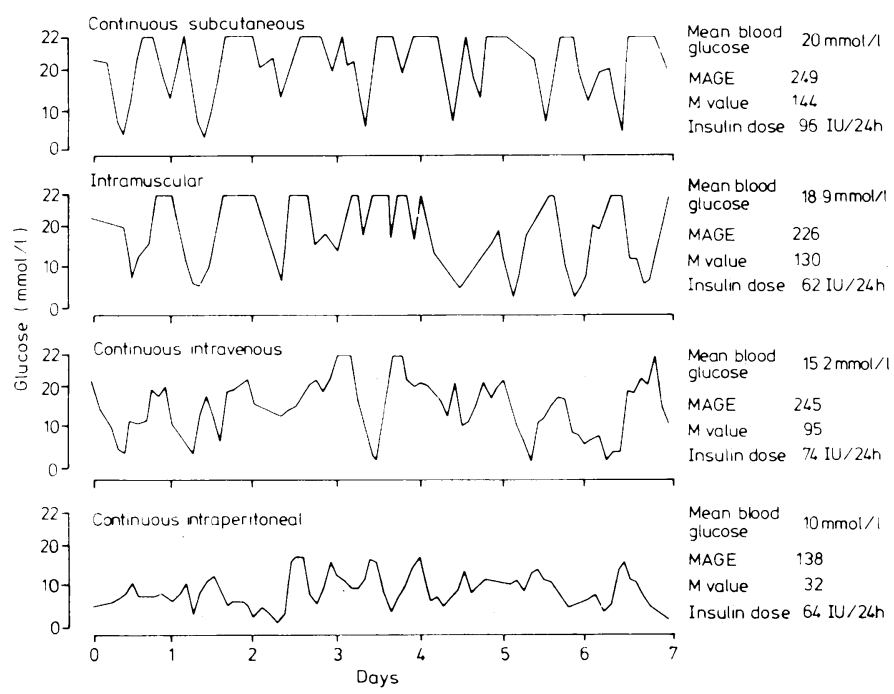

Seven-day glycaemic profiles during continuous subcutaneous, intramuscular, continuous intravenous, and continuous intraperitoneal administration of insulin.

MAGE $=$ Mean amplitude of glycaemic excursions.

Conversion: SI to traditional units-Glucose: $1 \mathrm{mmol} / 1 \approx 18 \mathrm{mg} / 100 \mathrm{ml}$. different treatments, giving the mean blood glucose concentration, mean amplitude of glycaemic excursions, $M$ value, and daily insulin requirement. Intramuscular administration of insulin did not appear $c$ to confer any metabolic advantage over subcutaneous administration, $\widehat{\supset}$ although less insulin was required. Continuous intravenous administration induced a slight reduction in mean blood glucose concentration and $M$ value but not in the mean amplitude of glycaemic $\mathbb{D}$ excursions. The intraperitoneal route yielded an improvement in all three variables and a reduction in the daily insulin requirement $\Omega$ compared with the subcutaneous, intramuscular, and intravenous:approaches.

The daily insulin requirement during intraperitoneal treatment was $\stackrel{\oplus}{\rightarrow}$ 64 IU (24 IU were given basally, 1 IU per hour, and three insulin supplements of 10,16 , and 14 IU were added at 0730,1230 , and 1930 음 respectively, starting 30 minutes before meals; all supplements $\frac{\omega}{\supset}$

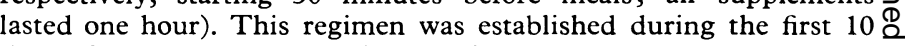
days of treatment and remained unchanged.

\section{Discussion}

This woman with brittle diabetes did not show any improvement when continuous subcutaneous, intramuscular, or con- -3 . tinuous intravenous insulin was administered. Intraperitoneal administration of insulin achieved a metabolic improvement, $\dot{\sigma}$ although blood glucose concentrations were still raised, despite $\mathscr{L}_{\mathscr{S}}$ a few isolated hypoglycaemic episodes. The patient subsequently $\overrightarrow{\vec{r}}$ wore the catheter for more than 120 days without any adverse of effects.

The intraperitoneal approach has the advantage of delivering insulin at a more physiological site, since the hormone reaches $\mathrm{N}$ the liver before entering the peripheral circulation. The risk of infection is restricted to the area close to the tip of the catheter, $\vec{c}$ and mechanical injuries are likely to occur rarely.

\section{References}

${ }^{1}$ Pickup JC, Home PD, Bilous RW, Kenn H, Alberti KGMM. Management of severely brittle diabetes by continuous subcutaneous and intramuscular insulin infusion: evidence for a defect in subcutaneous insulin absorption. Br Med f $1981 ; 282: 347-50$.

2 Service FJ, Malnar GD, Rosevear JW, Ackerman E, Gatewood LC, Taylor WF. Mean amplitude of glycemic excursions, a measure of $\vec{A}$ diabetic instability. Diabetes 1970;19:644-55.

${ }^{3}$ Schlichtkrull J, Munck O, Jersild $M$. The $M$ value, an index of bloodsugar control in diabetics. Acta Med Scand 1965;177:95-102.

(Accepted 4 October 1982)
ONE HUNDRED YEARS AGO However suitable, as a valuable tonic restorative, bathing in the open sea may be in the case of any particular person, the good effects of a sea-bath may be missed if the bather do not give heed to certain well ascertained rules which ought to guide his proceedings. The good effects of a plunge in the sea are in proportion to the vigour of the reaction which is excited in the bather's body by the shock of immersion. The more marked and prolonged the reaction the better; it should be the bather's object, to quote the words of an eminent physician, to secure the greatest possible amount of stimulation, and to ensure as long as possible the persistence of the increased vigour of nutrition. The time of bathing is important. It is a common error to suppose it is best to bathe before breakfast. The very robust may possibly bathe then with impunity, but, even for them, the practice of plunging into the sea in the early morning, fasting, is not free from risk; while, for the weakly, such course is positively prejudicial. After the long fast of the sleeping hours, the vital functions fall to a relatively low ebb, and they are liable to undue depression from such a severe shock as a cold sea-bath. Neither ought bathing to be practised immediately after taking a meal; it is then likely to cause troublesome symptoms by suddenly arresting the digestive processes. Probably the best results are obtainable from sea-bathing at a time midway between breakfast and luncheon, that is, from two to three hours after the early morning meal, when the body has been nourished after the fasting of the night, and when the stomach has had time in great part to dispose of its contents. AN bather should never enter the sea whilst under the influence of emotional excitement; if the nervous force be unduly concentratedo in any single direction, a sea-bath is likely to produce nervous depression rather than stimulation. A bather should not stand hesitatingly by the water's edge until he becomes cold and shivering but plunge bodly into the sea at once. It is another popular error to suppose that the skin should be cooled before entering the sea; if the bather be chilled just before his bath, circulatory depression rathe than reaction is apt to arise, leaving him with a sense of coldness and weakness rather than of warmth and invigoration. To get its best results, a sea-bath must not be too prolonged. It has been laid down as a rule by a well known authority that no one bathing for health only should remain in the open sea for more than ten minutes. Even $\stackrel{\mathbb{2}}{2}$ shorter immersion than this will probably best suit all but the strongest persons. The bather must not stay in the sea until the reactive stimulation of his bath has passed away. His object ought to be to excite an energetic reaction, and then to leave the water. Fromo too long immersion in the open sea, the skin becomes unduly cooled? and the circulation and nervous system depressed, so that exhaustion. malaise, and shivering are apt to arise, instead of a feeling of renewed vigour, well-being, and warmth. (British Medical fournal, 1883 ;ii :24.) 